\title{
Pleural effusion. An unfamiliar presentation of ABPA
}

\author{
Komaldeep Kaur, Aditi Gupta, Gagandeep Kaur, Vishal Chopra \\ Department of Pulmonary Medicine, Government Medical College, Patiala, India
}

\begin{abstract}
Pleural effusion is rarely encountered in patients of allergic bronchopulmonary aspergillosis (ABPA). We report the case of a 17-year-old male who presented with complaints of fever, cough and increasing shortness of breath for 3 weeks. Patient had breathlessness with seasonal variation. Patient had right lower lobe consolidation with pleural effusion which did not respond to antibiotics. Pleural fluid was exudate with neutrophilic predominance and low ADA. Skin prick test for aspergillus fumigatus was positive, both total $\operatorname{IgE}$ and specific $\mathrm{IgE}$ against aspergillus fumigatus were raised.
\end{abstract}

\section{Introduction}

Allergic bronchopulmonary aspergillosis (ABPA) is a complex immunological pulmonary disorder caused by hypersensitivity to Aspergillus species, mainly Aspergillus fumigatus [1].

Correspondence: Dr. Komaldeep Kaur, Department of Pulmonary Medicine, Government Medical College, H. No. 560, Indra Nagar, Nangal, Roopnagar, Punjab, India.

Mobile: +91.9464391818 .

E-mail: bhatti.komal@gmail.com

Keywords: Allergic bronchopulmonary aspergillosis; asthma; pleural effusion.

Authors' contributions: All the authors have equally contributed to the manuscript. All the authors have read and approved the final version of the manuscript and agreed to be accountable for all aspects of the work.

Conflict of interest: All the authors declare no conflict of interest.

Funding: not applicable.

Informed consent: Informed consent was taken from the patient.

Received for publication: 15 May 2020.

Accepted for publication: 8 July 2020.

${ }^{\circ}$ Copyright: the Author(s), 2020

Licensee PAGEPress, Italy

Monaldi Archives for Chest Disease 2020; 90:1380

doi: 10.4081/monaldi.2020.1380

This article is distributed under the terms of the Creative Commons Attribution Noncommercial License (by-nc 4.0) which permits any noncommercial use, distribution, and reproduction in any medium, provided the original author(s) and source are credited.
The disease presents with varied clinical and radiological manifestations ranging from an asymptomatic patient with or without pulmonary infiltrates to severe uncontrolled asthma with or without central bronchiectasis (CB) and pulmonary fibrosis [2]. The diagnosis is mainly based on clinical suspicion in patients of asthma and on total and Aspergillus specific IgE levels. Pleural effusion is a rare feature in ABPA. We report a case of pleural effusion related to ABPA as initial pathology presentation.

\section{Case Report}

A 17-year-old male, presented with history of fever, cough with expectoration and shortness of breath for 3 weeks. Patient had history of dust allergy and wheeze with seasonal variation since childhood. History of occasional nebulization therapy use was present but there was no history of use of regular controller therapy. Patient did not give any history of tuberculosis in the past. There was no family history of bronchial asthma. On physical examination, patient was febrile $\left(39.4^{\circ} \mathrm{C}\right)$, heart rate $100 / \mathrm{min}$, blood pressure $120 / 70 \mathrm{mmHg}$, respiratory rate $20 / \mathrm{min}$. On examination, there was dull percussion note with decreased breath sounds in right infrascapular area and bilateral rhonchi. Chest X-ray was suggestive of right sided pleural effusion with consolidation (Figure 1). Total leucocyte count (TLC) was $14,800 \mathrm{~mm}^{3}$ with neutrophilic predominance and absolute eosinophilic count (AEC) count of $558 \mathrm{~mm}^{3}$. Sputum for AFB was negative and pyogenic cultures were also sterile. Mantoux test was negative and ESR was $5 \mathrm{~mm} / 1^{\text {st }} \mathrm{h}$. Computed tomography of chest revealed central bronchiectasis with collapse consolidation in right lower lobe along with pleural effusion (Figure 2). Straw colored pleural fluid was aspirated which showed TLC$450 \mathrm{~mm}^{3}$ with neutrophilic (80\%) predominance, LDH $1654 \mathrm{U} / 1$, proteins $4.90 \mathrm{~g} / \mathrm{dl}$, glucose $3 \mathrm{mg} / \mathrm{dl}$, choride $102 \mathrm{mmol} / \mathrm{l}$ and ADA 14 IU/L. Pleural fluid was negative for AFB on $\mathrm{ZN}$ staining and GeneXpert. Pyogenic and fungal cultures were sterile and fluid was negative for malignant cytology. Skin prick test for A. fumigatus was positive. Total IgE and specific IgE against $A$. fumigatus were markedly elevated with values of $13705 \mathrm{KU} / \mathrm{L}$ and $54.70 \mathrm{kuA} / \mathrm{L}$ respectively. A diagnosis of ABPA was made and patient was put on oral prednisolone in a dose of $0.75 \mathrm{mg} / \mathrm{kg}$ body weight which was tapered gradually over six months along with antifungal (itraconazole) for 16 weeks to which he improved. After six weeks of follow up, chest radiograph (Figure 3) showed complete resolution of consolidation and effusion.

\section{Discussion}

As to our knowledge very few cases in relation to ABPA associated pleural effusion have been reported. Many of those 
patients had prior history of asthma and were on controller medications [3-7]. Typically, patients of ABPA present with poorly controlled asthma, wheezing, hemoptysis and productive cough [8]. Among all the patients of ABPA with bronchial and pleural involvement as per CT imaging, only $<0.5 \%$ had pleural effusion according to Panchal et al. [9].

Inhaled conidia of Aspergillus can persist and germinate into fungal hyphae in genetically predisposed asthmatic individuals leading to profound inflammatory process in the airways $[10,11]$. This further leads to release of cytokines and fungal translocation into the pleural space, leading to a local Th2-dependent inflammatory response. This has been postulated as the possible mechanism for the development of pleural effusion [5].

In countries where there is high prevalence of tuberculosis (TB), patients of ABPA are commonly misdiagnosed as TB, and put on antitubercular therapy. Pleural fluid in our patient was neutrophilic and exudative with low ADA which ruled out TB. ABPA was diagnosed as per Agarwal criteria [12] which includes obligatory criteria [type I Aspergillus skin test positive or elevated IgE levels against $A$. fumigatus and elevated total $\operatorname{IgE}$ levels $(>1000 \mathrm{IU} / \mathrm{mL})]$ and other criteria (presence of precipitating or IgG antibodies against $A$. fumigatus in serum; radiographic pulmonary opacities consistent with ABPA and total eosinophil count $>500$ cells/lL). For fulfilling the criteria, both obligatory and two out of three other criteria should be met in patients with underlying bronchial asthma or cystic fibrosis. Systemic glucocorticoids suppress the immune activity and antifungal agents attenuate the fungal load in the airways [13]. Treatment includes oral prednisolone of $0.5-0.75 \mathrm{mg} / \mathrm{kg}$ gradually tapered over $6-12$ months and oral antifungals for 16 weeks duration. The patient

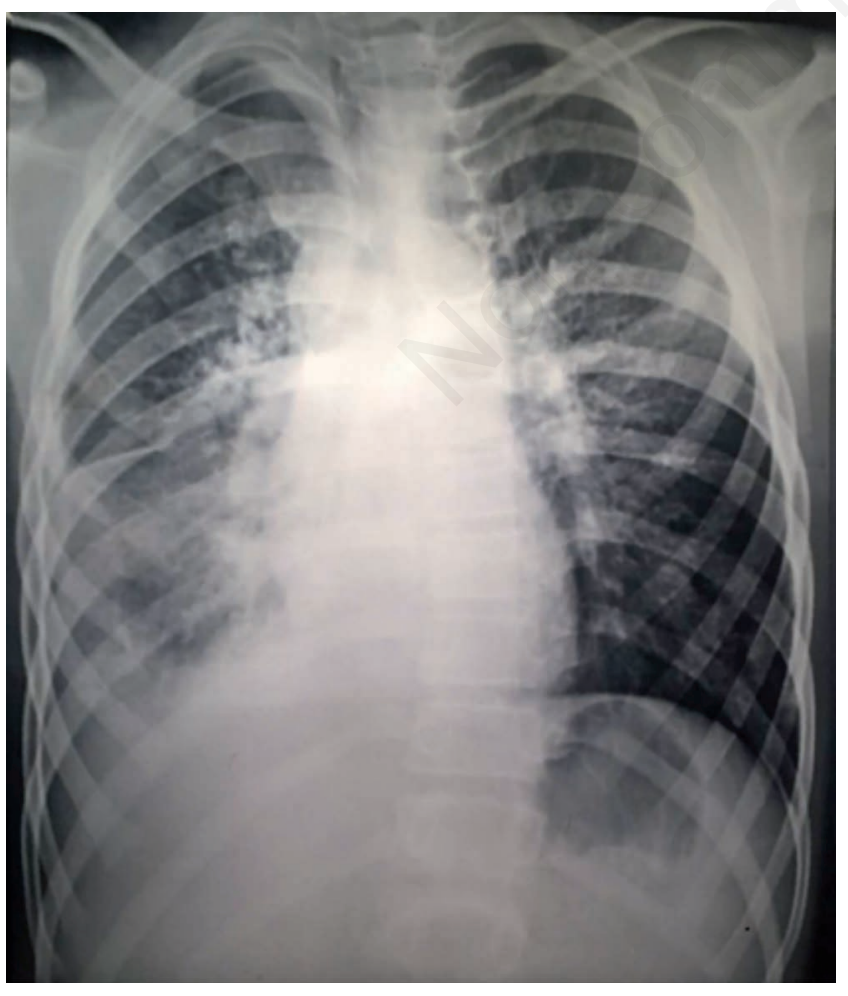

Figure 1. Chest $\mathrm{X}$-ray suggestive of consolidation with right sided pleural effusion. was put on steroids and anti fungal medications. There was clinical and radiological improvement.

Though ABPA is a rare cause of pleural effusion (Table 1), this case highlights that ABPA should be kept in differential diagnosis in patients of pleural effusion with history of asthma even in countries with high prevalence of tuberculosis.

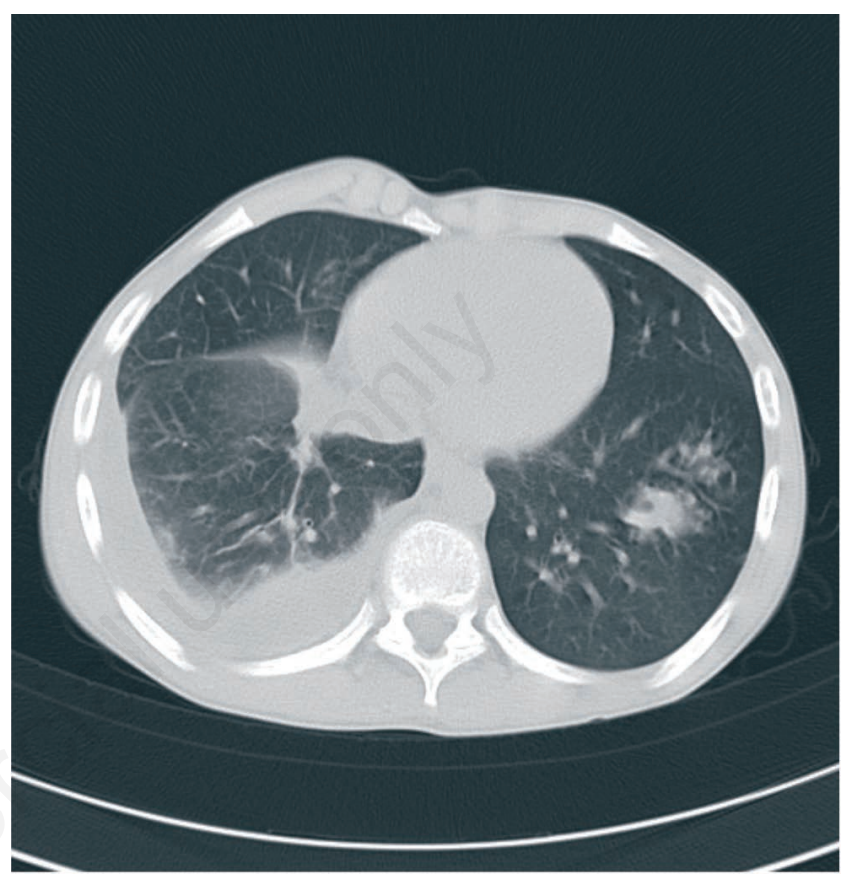

Figure 2. Computed tomography of chest showing right sided pleural effusion.

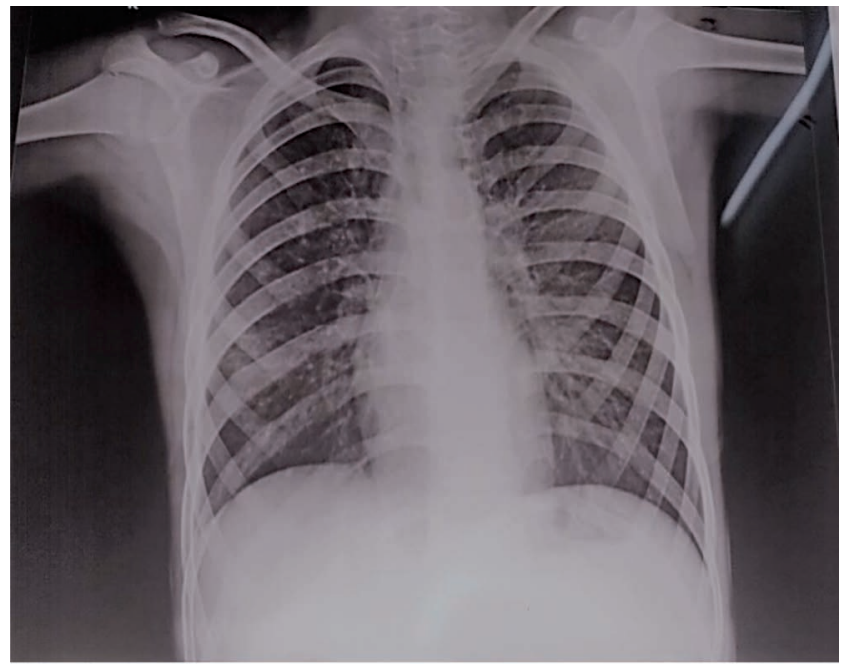

Figure 3. Follow up chest X-ray showing resolution of pleural effusion with treatment. 
Table 1. Details of previous cases reported as ABPA associated pleural effusions in literature till date.

\begin{tabular}{|c|c|c|c|c|c|c|c|c|c|}
\hline $\begin{array}{l}\text { Author - } \\
\text { Year of } \\
\text { publication }\end{array}$ & Age/Gender & $\begin{array}{l}\text { History } \\
\text { of } \\
\text { asthma }\end{array}$ & $\begin{array}{l}\text { Skin } \\
\text { prick } \\
\text { test }\end{array}$ & $\begin{array}{l}\text { S. } \\
\text { preci- } \\
\text { pitins }\end{array}$ & $\begin{array}{l}\text { IgE } \\
\text { (total } \\
\text { and } \\
\text { Asper- } \\
\text { gillus } \\
\text { specific) }\end{array}$ & $\begin{array}{l}\text { Radiological } \\
\text { findings }\end{array}$ & $\begin{array}{l}\text { Final } \\
\text { diagnosis }\end{array}$ & $\begin{array}{l}\text { Treatment } \\
\text { given }\end{array}$ & Follow up \\
\hline $\begin{array}{l}\text { Murphy et al. [3] } \\
1981\end{array}$ & $12 \mathrm{yrs} / \mathrm{male}$ & Yes & Positive & Positive & NA & $\begin{array}{l}\text { Left sided pleural } \\
\text { effusion }\end{array}$ & ABPA & Steroids & $\begin{array}{l}\text { Resolution of } \\
\text { pleural effusion }\end{array}$ \\
\hline $\begin{array}{l}\text { Murphy et al. [3] } \\
1981\end{array}$ & $64 \mathrm{yrs} / \mathrm{male}$ & Yes & Positive & Positive & NA & $\begin{array}{l}\text { Left pleural effusion, } \\
\text { partial collapse of } \\
\text { left upper and right } \\
\text { middle lobe } \\
\text { andmediastinal } \\
\text { lymphadenopathy }\end{array}$ & $\mathrm{ABPA}$ & Steroids & $\begin{array}{l}\text { Resolution at } 3 \text { months; } \\
\text { Recurrence while } \\
\text { tapering steroid dose } \\
\text { which responded to } \\
\text { increase in steroid } \\
\text { dose }\end{array}$ \\
\hline $\begin{array}{l}\text { Bhagat et al. [6] } \\
1993\end{array}$ & 38 yrs / female & Yes & Positive & Positive & $\mathrm{NA}$ & $\begin{array}{l}\text { Left lung collapse } \\
\text { with effusion }\end{array}$ & $\mathrm{ABPA}$ & Steroids & $\begin{array}{l}\text { Resolution at one } \\
\text { month }\end{array}$ \\
\hline $\begin{array}{l}\text { Panchal et al. [9] } \\
1997\end{array}$ & $54 \mathrm{yrs} / \mathrm{male}$ & Yes & Positive & Positive & Elevated & $\begin{array}{l}\text { Left lower } \\
\text { lobectomy with } \\
\text { collapse of the } \\
\text { remaining two } \\
\text { left lobes and } \\
\text { psilateral pleural } \\
\text { effusion }\end{array}$ & $\mathrm{ABPA}$ & Steroids + ant & ifungals \\
\hline $\begin{array}{l}\text { Connor et al. }[4] \\
2001\end{array}$ & $27 \mathrm{yrs} / \mathrm{male}$ & Yes & Positive & Positive & Elevated & $\begin{array}{l}\text { Bilateral effusion } \\
\text { and bilateral } \\
\text { perihilar opacities } \\
\text { and left lower } \\
\text { lobe infiltrates }\end{array}$ & $\mathrm{ABPA}$ & Steroids & Resolution at 3 months \\
\hline $\begin{array}{l}\text { Ogasawara et al. } \\
\text { [14]2003 }\end{array}$ & $61 \mathrm{yrs} / \mathrm{male}$ & Yes & Positive & Positive & Elevated & $\begin{array}{l}\text { Lung infiltrates } \\
\text { Right sided } \\
\text { effusion developed } \\
\text { while on steroids }\end{array}$ & ABPA & $\begin{array}{l}\text { Steroids }+ \\
\text { antifungals }\end{array}$ & $\begin{array}{l}\text { Resolution after } \\
\text { increasing steroid dose }\end{array}$ \\
\hline $\begin{array}{l}\text { Kirschner et al. [5] } \\
2011\end{array}$ & $25 \mathrm{yrs} / \mathrm{male}$ & Yes & $\mathrm{NA}$ & NA & Elevated & $\begin{array}{l}\text { Left upper lobe } \\
\text { atelectasis and } \\
\text { pleural effusion }\end{array}$ & $\mathrm{ABPA}$ & $\begin{array}{l}\text { Steroids } \\
\text { antifungals }\end{array}$ & Resolution at 6 months \\
\hline $\begin{array}{l}\text { Madan et al. [7] } \\
2012\end{array}$ & 22 yrs / female & Yes & Positive & Positive & Elevated & $\begin{array}{l}\text { Right sided pleural } \\
\text { effusion }\end{array}$ & $\begin{array}{l}\text { ABPA with } \\
\text { Tubercular } \\
\text { effusion }\end{array}$ & $\begin{array}{l}\text { Anti- } \\
\text { tubercular } \\
\text { therapy }\end{array}$ & Resolution at 2 months \\
\hline
\end{tabular}

NA, not available; ABPA, Allergic bronchopulmonary aspergillosis.

\section{References}

1. Agarwal R. Allergic bronchopulmonary aspergillosis. Chest 2009;135:805-26.

2. Rosenberg M, Patterson R, Mintzer R, et al. Clinical and immunologic criteria for the diagnosis of allergic bronchopulmonary aspergillosis. Ann Intern Med 1977;86: 405-14.

3. Murphy D, Lane DJ. Pleural effusion in allergic bronchopulmonary aspergillosis: Two case reports. Br J Dis Chest 1981;75:91-5.

4. O'Connor TM, O'Donnell A, Hurley M, Bredin CP. Allergic bronchopulmonary aspergillosis: A rare cause of pleural effusion. Respirology 2001;6:361-3.

5. Kirschner AN, Kuhlmann E, Kuzniar TJ. Eosinophilic pleural effusion complicating allergic bronchopulmonary aspergillosis. Respiration 2011;82:478-81.

6. Bhagat R, Shah A, Jaggi OP, Khan ZU. Concomitant allergic bronchopulmonary aspergillosis and allergic Aspergillus sinusitis with an operated aspergilloma. J Allergy Clin Immunol 1993;91:1094-6.

7. Madan K, Bal A, Agarwal R. Pleural effusion in a patient with allergic bronchopulmonary aspergillosis. Respir Care 2012;57:1509-13.

8. Agarwal R, Chakrabarti A. Clinical manifestations and natural history of allergic bronchopulmonary aspergillosis. In: A. Comarù Pasqualotto, editor. Aspergillosis: From diagnosis to prevention. Springer; 2010. p. 707-24.

9. Panchal N, Bhagat R, Pant C, Shah A. Allergic bronchopulmonary aspergillosis: The spectrum of computed tomography appearances. Respir Med 1997;91:213-9.

10. Tomee JFC, Wierenga ATJ, Hiemstra PS, Kauffman HF. Proteases from Aspergillus fumigatus Induce release of proinflammatory cytokines and cell detachment in airway epithelial cell lines. J Infect Dis 1997;176:300-3.

11. Kauffman HF, Christomee JF, Van De Riet MA, et al. Proteasedependent activation of epithelial cells by fungal allergens leads to morphologic changes and cytokine production. J Allergy Clin Immunol 2000;105:1185-93. 
12. Agarwal R, Chakrabarti A, Shah A, et al. Allergic bronchopulmonary aspergillosis: Review of literature and proposal of new diagnostic and classification criteria. Clin Exp Allergy 2013;43:850-73.

13. Moss RB. Critique of trials in allergic bronchopulmonary aspergillosis and fungal allergy. Med Mycol 2006;44:S269-72. 14. Ogasawara T, Iesato K, Okabe H, et al. A case of pleural effusion associated with allergic bronchopulmonary aspergillosis during a relapse of the disease. Nihon Kokyuki Gakkai Zasshi 2003;41:905-10. 